\title{
Study of Orthopedic Deformities in Female Judokas of School Age
}

\author{
Irma de las Mercedes Muñoz Aguilar ${ }^{1 *}$ and Rafael Lázaro Tamarit Medrano ${ }^{2}$ \\ ${ }^{1}$ PhD in Physical Culture Sciences, Faculty of Physical Culture, University of Camagüey, Cuba \\ ${ }^{2}$ Doctor of Physical Culture Sciences, Faculty of Physical Culture, University of Camagüey, Cuba
}

Received: 眥 October 16, 2018 Published: 眥 October 24, 2018

*Corresponding author: Irma de las Mercedes Muñoz Aguilar, PhD in Physical Culture Sciences, Faculty of Physical Culture, University of Camagüey, Cuba

\begin{abstract}
This article reports a study carried out with the population of female judo athletes aged between 13 and 14 years, from the Sports Initiation School of Camagüey, Cuba, for the determination of the orthopedic deformities presented, the results obtained corroborate the presence of deformities, combined in all cases, which are not attributed to sports, but to the selection, but can be aggravated if the correct execution of the technical elements of this sport is not addressed and strategies are not established to correct them in the context of sports training, to prevent them from consolidating in the future.
\end{abstract}

Keywords: Middle school age; Judo; Orthopedic deformities

\section{Introduction}

In the average school age, comprised of 12 to 16 years, the bone tissue has the characteristic structure of adults, but the ossification of the spine and the symphysis of some skeletal bones has not yet ended, so that the bones are impermissible. Large physical loads, especially unilateral, is for this reason that moderate exercises are recommended to strengthen the bone tissue and the formation of a correct posture. The term posture in the sense given to it in medical practice means the relative position or disposition of each portion of the body in relation to the adjacent segments and with respect to the body as a whole [1]. The normal posture is characterized by the symmetrical distribution of the parts of the body, in relation to the spine. Deviations from normal posture are usually referred to as alterations or defects of the posture and may be related to functional variations of the locomotor system, which cause the formation of vicious conditioned reflex relationships, and fix an incorrect position of the body, causing lose partially or totally, the habit of correct posture [2]. In this age group the muscular system develops progressively, increases the strength and capacity for a more or less prolonged physical activity and adjusts the coordination of the movements. However, resistance and strength loads are still poorly supported, speed exercises are more easily assimilated. In this stage sexual maturity begins, in which high excitability and instability of the nervous system is observed, which makes it difficult to adapt to physical burdens. However, this process does not occur in people at the same age and requires an individual approach [3].
For these reasons, in high-performance sports practice it is essential to take into account the morphological, functional and psychological characteristics of athletes subjected to effort, because although it is true that systematic and correctly dosed physical activity causes an increase in musculoskeletal development and for this reason, it is of great importance to achieve good sporting results, it is also important to carry out a preparation that complies with these premises, since the consequences of the physical load badly applied on the athletes are manifested, naturally, after of certain time, which brings as consequence the appearance of anomalies in the structures of the body, which are known as orthopedic deformities; among others [4].

\section{Materials and Methods}

In order to carry out this work, we studied the population of 13 female judo athletes aged between 13 and 14 years, with two years of sporting age, belonging to the Sports Initiation School of Camagüey, Cuba. By means of the postural test, the orthopedic deformities were determined, the classification of foot deformities is used [5].

\section{Results and Discussion}

As for the deformities of lower limbs, it is noted that $30.8 \%$ have the first-degree flat foot where muscle tissue is affected and $69.2 \%$ flat foot of the second degree in which the tissue is already 
affected muscular joint and ligament, 100\% have the pronged foot, and $23 \%$ abduct, combination referred [6] and found in other populations [7]. This fact is motivated because the training of Judo requires long stays in bipedal position and barefoot on a rather soft surface, which favors the fall of the internal longitudinal arch and therefore the foot loses the cupular structure that guarantees normal support, in what is called Haller's tripod. In the front view, 46.1 have valgus knees, $30.8 \%$ have valved knees with tibial varas and 7.6 knees and in sagittal planes, the presence of hyperextended knees was observed in $15.3 \%$.

By observing the technical elements that characterize the Judo training, it was detected that when the static work is done in pairs, and one of the athletes adopts the position of defense of UKE, to receive the input of TORI, it could be noted that, the athlete who performs the UKE work to balance the body rotates the knees inwards, something that is favored by the consistency of the training mattress used in this sports facility, however, this defense position is inadequate, as this must be from the natural position, with the legs separated approximately one foot away, slightly flexing the knees in such a way that the athlete does not see the toe, which causes the upper body to lower and the center of gravity of this, so the weight should be evenly distributed on both feet, and the face directed to the front, that is, that the adoption of this position observed use a technical error, but it is not attributed the presence of the knees valgus to this, but to the selection, that is to say that given the time that the athletes have been practicing this sport, that error does not constitute etiológico agent to produce such deformity, that is to say that when they started in the sport they already had it, but if only attention is paid at the time of work as a couple to the technical elements that constitute the attack and the defense position is not corrected, the continuity of this fact will provoke medium and long the progression of said deformity.

The orthopedic deformities of the spine in the frontal plane of the posterior view also reached the highest level of representation, since all of them presented scoliosis in " $\mathrm{C}$ " of the first degree where the muscle tissue is affected, $77 \%$ to the left, since they are right- handed and work they enter it from the right, which causes that shoulder to go down and in compensation the hip of that same side goes up, while $23 \%$ present it to the right and they are left-handed and the work described is done by the opposite side. In sagittal plane it was found that $23 \%$ have kyphotic back, $46 \% 1 \%$ lordotic back and 7,6\% kypholordotic back.

\section{Conclusion}

The presence of orthopedic deformities was found in all of the studied population, which are not attributed to sports practice, but rather to selection, since athletes have a very short sporting age. $100 \%$ have flat feet, since the training of Judo requires long stays in bipedal position and barefoot in a rather soft surface, which favors the fall of the internal longitudinal arch and therefore the foot loses the cupular structure which guarantees the normal support. The deformities detected in the knees in frontal plane seen before, are not a consequence of the errors in the execution of the technical elements of this sport, but to the selection. In the vertebral column seen in the posterior frontal plane, the presence of scoliosis was found in $\mathrm{C}$, which denotes the unilateral work that is carried out in the training.

\section{References}

1. Tamarit Medrano R (2003) Gimnasia Correctiva. (Soporte Digital) La Habana Inder.

2. Laptev A, A Minj (1987) Higiene de la Cultura Física y el deporte. Editorial Raduga. Moscow, Russia.

3. Karpman J (1987) Medicina Deportiva. Editorial Revolucionaria. La Habana, Cuba.

4. Álvarez R (1986) Tratado de cirugía ortopédica y traumatología. Editorial Pueblo y Educación. La Habana, Cuba, pp. 150-187.

5. Muñoz I (2006) Programa integrador dirigido al tratamiento de la multipresencia simultánea de deformidades ortopédicas en los portadores del Síndrome de Down. (Disertación doctoral). ISCF. La Habana.

6. Hernández R (1990) Morfología Funcional Deportiva: Sistema Locomotor. Editorial Científico Técnica. La Habana, Cuba.

7. Kudo K (1987) Judo en acción. Técnicas de proyección. Edición Revolucionaria. La Habana, Cuba.
This work is licensed under Creative Commons Attribution 4.0 License

To Submit Your Article Click Here: Submit Article

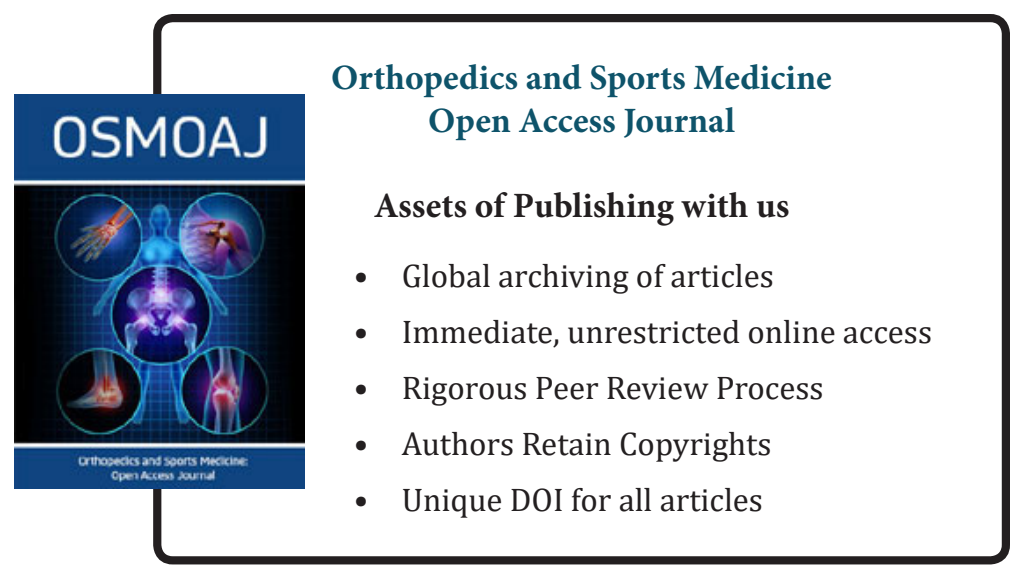

